\title{
Influence of zinc on Trichoderma harzianum and sheath blight of rice under glasshouse conditions
}

\author{
ASHRAF ALI KHAN ${ }^{1}$ AND RAJBIR SINGH* \\ Department of Plant Pathology, Gochar Mahavidyalaya, Rampur Maniharan, SAHARANPUR (U.P.) INDIA \\ ${ }^{1}$ Krishi Vigyan Kendra (C.S.A. Univ. of Agril. \& Tech.), ALIGARH (U.P.) INDIA
}

\section{ARITCLE INFO \\ Received : 01.07 .2015 \\ Revised : 16.08 .2015 \\ Accepted : 01.09 .2015}

\section{KEY WORDS :}

Rice, Sheath blight, Trichoderma harzianum, Rhizoctoniasolani, Zinc

*Corresponding author:

Email: rajbirsingh2810@gmail.com

\begin{abstract}
This study was carried out to know the effect of zinc on Trichoderma harzianum and sheath blight of rice under glasshouse conditions. The bio-agent significantly reduced the disease severity and incidence of sheath blight. Maximum reduction in disease severity $(52.66 \%)$ and incidence $(26.66 \%)$ was recorded when the zinc applied as foliar application in bio-agent treated pots it is followed by 36.80 per cent reduction in disease severity and 22.31 per cent in diseases incidence, respectively in pots where soil application of zinc was given in bio-agent treated pots. Minimum reduction in disease severity $(42.10 \%)$ and incidence $(22.31 \%)$ were recorded in pots without zinc application. The application of bio-agent significantly increased grain yield and 1000-grain weight. Maximum increase in grain yield $(19.38 \%)$ was recorded when zinc was applied in the soil followed by foliar application of bio-agent. Maximum increase in 1000-grain weight (7.10\%) was recorded in pots where foliar application of zinc and bio-agent was given. Minimum increase in 1000-grain weight (4.92\%) was reported in pots where zinc was not applied.
\end{abstract}

How to view point the article : Khan, Ashraf Ali and Singh, Rajbir (2015). Influence of zinc on Trichoderma harzianum and sheath blight of rice under glasshouse conditions. Internat. J. Plant Protec., 8(2) : 303-306. 